\title{
STUDI KETAHANAN PANGAN PADA RUMAHTANGGA MISKIN DAN TIDAK MISKIN
}

\author{
Dadang Sukandar'; Ali Khomsan'; Hadi R. ${ }^{1}$; Faisal Anwar ${ }^{1}$ dan Eddy S. ${ }^{1}$ \\ ${ }^{1}$ Staf Pengajar Dept. Gizi Masyarakat FEMA_IPB
}

\begin{abstract}
Food security at household level refers to the ability to ensure an adequate intake of food for the whole family members. Food security includes physical (food availability), economical (purchasing power), nutritional (fulfilled individual need of adequate nutrient), cultural and religious aspects, health, and time. The objective of this study was to identify factors affecting food security of the households. The study was conducted in a highland area of Bogor District and a coastal area of Indramayu District, West Java, Indonesia. In Bogor, 375 samples and in Indramayu 376 samples were selected randomly. The data collected through questionnaires were tried out before hand so that they were more operational. The revised questionnaires and forms then were used by the enumerators. Food security reflected by the sufficiency level of energy and protein intake shows that in general poor households have a low level of nutritional. Households in Indramayu have a higher food security than those in Bogor (particularly in terms of protein sufficiency). Factors having a significant association on food security of households were the number of household members, husband ages, and household category. The number of members in households affect significantly the energy sufficiency level. The number of members in households, husbands' ages, and household category have a significant effect on the level of protein sufficiency.
\end{abstract}

Key words: food security, energy sufficiency, protein sufficiency.

\section{PENDAHULUAN}

Definisi ketahanan pangan menurut Departemen Pertanian 2001 adalah kondisi terpenuhinya pangan bagi rumahtangga yang tercermin dari : (1) tersedianya pangan secara cukup, baik dalam jumlah maupun mutunya; (2) aman; (3) merata; (4) terjangkau. Ketahanan pangan ini mencakup dimensi fisik pangan (ketersediaan), ekonomi (daya beli), pemenuhan kebutuhan gizi individu (dimensi gizi), nilai-nilai budaya dan religi, ketahanan pangan (kesehatan), dan waktu (tersedia secara berkesinam-bungan) (1).

Ketahanan pangan di tingkat rumahtangga dimaksudkan dengan kemampuan sebuah keluarga untuk cukup tahan dalam hal pangan untuk menjamin kecukupan intake makan-an bagi seluruh anggota keluarga. Atmojo, Syarief, Sukandar, \& Latifah ${ }^{(2)}$ menyebutkan bahwa kondisi ketidaktahanan pangan rumahtangga ada dua bentuk yaitu: (a) ketidaktahanan pangan kronis yaitu terjadi dan berlangsung secara terus menerus yang biasanya disebabkan oleh rendahnya daya beli dan kualitas sumberdaya yang sering terjadi di wilayah yang miskin dan gersang; (b) ketidaktahanan pangan akut, terjadi secara mendadak yang disebabkan oleh bencana alam, kegagalan produksi dan kenaikan harga yang mengakibatkan masyarakat sukar memper-oleh pangan yang memadai.

Ketahanan pangan merupakan konsep yang multidimensi yaitu meliputi mata rantai sistem pangan dan gizi mulai dari produksi, distribusi, konsumsi dan status gizi. Situasi sistem ketahanan pangan rumahtangga dinilai dari ukuran yang dikembangkan dari berbagai indikator. Berdasarkan sistem pangan dan gizi tersebut, Chung ${ }^{(3)}$ merangkum beragam indikator ketahanan pangan rumahtangga sesuai dengan aspek ketersediaan, akses dan konsumsi pangan.

Aspek ketersediaan pangan tergantung pada sumberdaya alam, fisik, dan manusia serta produksi pertanian maupun non 
pertanian. Akses pangan meliputi pendapatan baik dari pertanian maupun non pertanian. Indikator yang dipakai adalah total pendapatan, pendapatan dari tanaman, pendapatan dari ternak, upah, harga pangan, pasar, dan akses jalan.

Akses pangan tertuju pada strategi berbagai kemudahan untuk sumberdaya pangan. Pangan dapat berada dalam sebuah keluarga dengan berbagai cara, baik melalui produksi, pembelian, dan pinjaman (pemberian). Sumber akses pangan termasuk akses produktif (lahan dan ternak), aset non-produktif (misal: perhiasan), aset manusia (tenaga kerja, pendidikan, kesehatan), pendapatan (aktivitas tani dan non-tani), dan klaim (pinjaman atau hadiah) (4).

Pola konsumsi pangan seseorang atau masyarakat menurut Harper, Deaton dan Driskel( $^{(5)}$ dipengaruhi oleh ketersediaan pangan, pola sosial budaya dan pribadi. Ketersediaan pangan dipengaruhi oleh produksi pangan dan pendapatan yang menentukan daya beli seseorang atau sebuah keluarga terhadap pangan. Status sosial budaya seperti sikap, kebiasaan makan tabu terhadap makanan, ketidaktahuan akan gizi dan distribusi pangan dalam keluarga juga akan mempengaruhi ketidakcukupan ketersediaan pangan.

Indikator yang biasa digunakan untuk menganalisis masalah kerawanan pangan (food insecurity) adalah konsumsi energi dan protein. Apabila seseorang atau rumahtangga mengkonsumsi energi dan atau protein kurang dari $70 \%$ angka kecukupan (Recommended Dietary Allowances), maka seseorang atau rumahtangga tersebut tergolong rawan pangan (food insecured). Pada tingkat wilayah atau nasional indikatornya adalah persentase penduduk atau rumahtangga yang rawan pangan.

Kerawanan pangan merupakan konsep yang cukup kompleks, maka biasanya dibuat beberapa ukuran kerawanan pangan yang lebih sederhana. Salah satu ukuran kerawanan pangan yang dikembangkan oleh FAO (2002) dan digunakan secara luas adalah ukuran kurang pangan (undernourishment). Istilah kurang pangan (undernourishment) yang digunakan adalah status asupan pangan seseorang yang tidak cukup secara terus menerus untuk memenuhi kebutuhan energi dasar, yang diistilahkan dengan kebutuhan fisiologi. Kebutuhan energi dasar ini adalah 1.55 kali energi metabolik basal (EMB) (sekitar 1800 kkal per hari untuk rata-rata orang dewasa). Oleh karena itu studi ini dilakukan untuk mengidentifikasi faktor-faktor yang mempengaruhi ketahanan pangan di daerah dataran rendah (pertanian) dan nelayan.

Penelitian ini merupakan bagian dari penelitian besar yang berjudul Studi Ketahanan Pangan dan Status Gizi pada Rumahtangga Miskin di Dataran Tinggi dan Rendah. Tujuan dari penelitian ini adalah untuk mengidentifikasi faktor-faktor yang mempengaruhi ketahanan pangan di tingkat rumahtangga.

\section{BAHAN DAN CARA}

\section{Desain, Tempat dan Waktu}

Penelitian ini menggunakan desain case control group. Sampel kontrol adalah keluarga tidak miskin. Penelitian dilakukan di dua daerah yaitu Bogor (dataran tinggi) dan Indramayu (nelayan) dan masingmasing daerah diwakili oleh 3 (tiga) kecamatan. Daerah Bogor meliputi Kecamatan Ciomas, Dramaga dan Ciampea. Sedangkan di Indramayu meliputi Kecamatan Losarang, Kandanghaur, dan Sukra. Penelitian dilakukan selama 12 bulan yang dimulai pada November 2004 dan berakhir pada November 2005.

\section{Contoh dan Cara Pengambilan Contoh}

Sampel dalam penelitian ini adalah rumahtangga yang terdiri dari ayah dan ibu dengan kriteria utama yaitu memiliki sekurang-kurangnya 1 (satu) anak balita dan memenuhi kriteria miskin atau tidak miskin menurut BKKBN. Penarikan contoh dilakukan dengan menggunakan penarikan contoh acak pada kedua lokasi penelitian. Jumlah rumahtangga di Bogor yang menjadi contoh sebanyak 375 terdiri atas 248 rumahtangga miskin dan 127 rumahtangga 
tidak miskin. Jumlah rumahtangga contoh di Indramayu sebanyak 376, terdiri atas 265 rumahtangga miskin dan 111 rumahtangga tidak miskin.

\section{Pengolahan dan Analisis Data}

Data yang dikumpulkan dalam penelitian ini adalah status gizi anggota rumahtangga (umur, jenis kelamin, berat badan, dan tinggi badan orangtua dan balita), konsumsi energi dan protein. Pendugaan parameter yang bersifat umum meliputi pendugaan nilai rata-rata, simpangan baku (standar deviasi), nilai minimum, nilai maksimum bagi semua peubah kontinu, dan proporsi bagi peubah yang kategorikal atau peubah kontinu yang dikategorikan.

\section{HASIL DAN BAHASAN}

Indikator Konsumsi Energi Kurang dari $70 \%$

Survei konsumsi dilakukan pada tingkat rumahtangga, sehingga rumahtangga yang tergolong rawan pangan adalah rumahtangga yang konsumsi energi dan/atau proteinnya kurang dari $70 \%$ angka kecukupan. Dengan menggunakan indikator konsumsi energi kurang dari $70 \%$, sebanyak $41.5 \%$ rumahtangga di Bogor dan $44.0 \%$ rumahtangga di Indramayu tergolong rawan pangan.

Rumahtangga yang rawan pangan ini proporsinya sedikit lebih tinggi pada rumahtangga miskin dibandingkan rumahtangga tidak miskin. Data tersebut juga menunjukkan bahwa proporsi rumahtangga rawan pangan lebih tinggi di Indramayu dibandingkan dengan di Bogor.

Tabel 1

Sebaran Rumahtangga menurut Indikator Tingkat Kecukupan Energi

\begin{tabular}{|c|c|c|c|c|}
\hline \multirow{2}{*}{ Tingkat Kecukupan Energi (TKE) } & \multicolumn{2}{|c|}{ Bogor } & \multicolumn{2}{|c|}{ Indramayu } \\
\hline & $\mathrm{n}$ & $\%$ & $\mathrm{n}$ & $\%$ \\
\hline Miskin & \multicolumn{2}{|c|}{$(n=145)$} & \multicolumn{2}{|c|}{$(n=182)$} \\
\hline Rumahtangga Defisit Energi & 62 & 42.8 & 83 & 45.6 \\
\hline Rumahtangga Tidak Defisit Energi (TKE> 70\%) & 83 & 57.2 & 99 & 54.4 \\
\hline Tidak Miskin & \multicolumn{2}{|c|}{$(n=91)$} & \multicolumn{2}{|c|}{$(\mathrm{n}=77)$} \\
\hline Rumahtangga Defisit Energi & 36 & 39.6 & 31 & 40.3 \\
\hline Rumahtangga Tidak Defisit Energi (TKE> 70\%) & 55 & 60.4 & 46 & 59.7 \\
\hline Miskin + Tidak Miskin & \multicolumn{2}{|c|}{$(n=236)$} & \multicolumn{2}{|c|}{$(n=259)$} \\
\hline Rumahtangga Defisit Energi & 98 & 41.5 & $\overline{114}$ & 44.0 \\
\hline Rumahtangga Tidak Defisit Energi (TKE> 70\%) & 138 & 58.5 & 145 & 56.0 \\
\hline
\end{tabular}

\section{Indikator Konsumsi Protein Kurang dari $70 \%$}

Dengan menggunakan indikator konsumsi protein kurang dari $70 \%$, sebanyak $45.2 \%$ rumahtangga di Bogor dan 33.2\% rumahtangga di Indramayu tergolong rawan pangan (Tabel 2). Rumahtangga yang rawan pangan ini proporsinya jauh lebih tinggi pada rumahtangga miskin dibandingkan rumahtangga tidak miskin. Berbeda dengan hasil analisis indikator konsumsi energi, pada indikator konsumsi protein terlihat bahwa proporsi rumahtangga rawan pangan lebih tinggi di Bogor dibandingkan di Indramayu. 
Sebaran Rumahtangga menurut Indikator Tingkat Kecukupan Protein

\begin{tabular}{|c|c|c|c|c|}
\hline \multirow{2}{*}{ Tingkat Kecukupan Protein (TKP) } & \multicolumn{2}{|c|}{ Bogor } & \multicolumn{2}{|c|}{ Indramayu } \\
\hline & $n$ & $\%$ & $\mathrm{n}$ & $\%$ \\
\hline Miskin & \multicolumn{2}{|c|}{$(n=248)$} & \multicolumn{2}{|c|}{$(n=265)$} \\
\hline Rumahtangga Defisit Protein & 125 & 50.4 & 92 & 34.7 \\
\hline Rumahtangga Tidak Defisit Protein (TKP> 70\%) & 123 & 49.6 & 173 & 65.3 \\
\hline Tidak Miskin & \multicolumn{2}{|c|}{$(n=126)$} & \multicolumn{2}{|c|}{$(n=111)$} \\
\hline Rumahtangga Defisit Protein & 44 & 34.9 & 33 & 29.7 \\
\hline Rumahtangga Tidak Defisit Protein (TKP> 70\%) & 82 & 65.1 & 78 & 70.3 \\
\hline Miskin + Tidak Miskin & \multicolumn{2}{|c|}{$(n=374)$} & \multicolumn{2}{|c|}{$(n=376)$} \\
\hline Rumahtangga Defisit Protein & 169 & 45.2 & 125 & 33.2 \\
\hline Rumahtangga Tidak Defisit Protein (TKP> 70\%) & 205 & 54.8 & 251 & 66.8 \\
\hline
\end{tabular}

Dengan menggunakan gabung-an kedua indikator sebagai kriteria rawan pangan, yaitu rumahtangga yang konsumsi energi dan proteinnya kurang dari $70 \%$, maka ditemukan proporsi rumahtangga yang rawan pangan sebanyak $45.3 \%$ di Bogor dan $45.9 \%$ di Indramayu (Tabel 3).

Tabel 3

Sebaran Rumahtangga menurut Indikator Ketahanan Pangan

\begin{tabular}{|c|c|c|c|c|}
\hline \multirow{2}{*}{ Ketahanan Pangan } & \multicolumn{2}{|c|}{ Bogor } & \multicolumn{2}{|c|}{ Indramayu } \\
\hline & $\mathrm{n}$ & $\%$ & $\mathrm{n}$ & $\%$ \\
\hline Miskin & \multicolumn{2}{|c|}{$(n=145)$} & \multicolumn{2}{|c|}{$(n=182)$} \\
\hline Rumahtangga Tidak Tahan Pangan & 69 & 45.6 & 85 & 46.7 \\
\hline Rumahtangga Tahan Pangan & 76 & 52.4 & 97 & 53.3 \\
\hline Tidak Miskin & \multicolumn{2}{|c|}{$(n=91)$} & \multicolumn{2}{|c|}{$(n=77)$} \\
\hline Rumahtangga Tidak Tahan Pangan & 38 & 41.8 & 34 & 44.2 \\
\hline Rumahtangga Tahan Pangan & 53 & 58.2 & 43 & 55.8 \\
\hline Miskin + Tidak Miskin & \multicolumn{2}{|c|}{$(n=236)$} & \multicolumn{2}{|c|}{$(n=259)$} \\
\hline Rumahtangga Tidak Tahan Pangan & 107 & 45.3 & 119 & 45.9 \\
\hline Rumahtangga Tahan Pangan & 129 & 54.7 & 140 & 54.1 \\
\hline
\end{tabular}

Catatan : * Tahan pangan jika TKE $\geq 70 \%$ dan TKP $\geq 70 \%$

- Tidak tahan pangan jika TKE $\leq 70 \%$ dan TKP $\leq 70 \%$

\section{Faktor-faktor yang Mempengaruhi Ketahanan Pangan}

Peubah bebas yang berpenga-ruh secara nyata $(a=0.05)$ terhadap Tingkat Kecukupan Energi (TKE) adalah Jumlah Anggota Rumah-tangga (JAR). Semakin banyak anggota rumahtangga semakin kecil tingkat kecukupan energi. Namun peubah bebas ini hanya dapat menjelaskan tingkat kecukupan energi sebesar $9.43 \%$.

Tingkat kecukupan protein (TKP) dipengaruhi secara sangat nyata $(\alpha=0.01)$ oleh Jumlah Anggota Rumahtangga (JAR), Umur Suami (US), dan Kategori Keluarga (K1, K3). Semakin banyak jumlah anggota rumahtangga semakin kecil TKP. Sebaliknya semakin tinggi umur suami, semakin tinggi 
TKP. Sementara rumahtangga miskin petani maupun non petani TKP-nya lebih rendah daripada rumahtangga tidak miskin seperti ditunjukkan oleh koefisien $\mathrm{K} 1$ dan $\mathrm{K} 3$ yang negatif. Namun demikian keempat peubah tersebut hanya mampu menjelaskan 9.57 keragaman dari TKP.

Dari hasil analisis regresi diketahui bahwa peubah yang berpengaruh terhadap ketahanan pangan adalah jumlah anggota rumahtangga dan umur suami ( $\alpha=0.05$ ). Makin banyak anggota rumahtangga maka semakin rendah peluang suatu rumahtangga akan tahan pangan, dan semakin tinggi umur suami semakin tinggi peluang ketahanan pangan rumahtangga.

Tabel 4

Hasil Analisis Regresi Logistik

\begin{tabular}{|l|c|c|c|}
\hline \multicolumn{1}{|c|}{ Variabel } & Koefisien & Chi-Square & $\begin{array}{c}\text { Probabiliti }>\text { Chi } \\
\text { square }\end{array}$ \\
\hline - Intersep & -0.1966 & 0.0771 & 0.7812 \\
\hline - Jumlah Anggota keluarga & -0.6685 & 27.6009 & 0.0001 \\
\hline - Umur & 0.0319 & 3.8976 & 0.0484 \\
\hline - Pendidikan Isteri & -0.0516 & 1.3720 & 0.2415 \\
\hline
\end{tabular}

\section{Karakteristik Rumahtangga Tahan Pangan}

Pada Tabel 5 terlihat bahwa ciri utama rumahtangga tidak tahan pangan (food insecured) adalah pendapatan per kapita per bulan yang lebih rendah dibandingkan dengan rumahtangga yang tahan pangan. Ciri kedua adalah pengeluaran pangan yang lebih rendah. Ciri ketiga adalah status gizi yang lebih rendah yang disindikasikan dengan nilai z-skor BB/U dan BB/TB anak balita yang lebih negatif. Ciri keempat adalah properti rumahtangga miskin yang lebih besar. Ciri kelima adalah ukuran rumahtangga yang lebih besar (lebih dari lima orang/rumahtangga). Ciri kelima adalah intik energi dan zat gizi yang jauh lebih rendah.

Dari ciri-ciri tersebut terlihat bahwa rumahtangga tidak tahan pangan (food insecured) sangat terkait dengan keadaan sosial ekonomi dan gizi anggota rumahtangga. Karakteristik rumah-tangga tahan pangan dan rumahtangga tidak tahan pangan di Bogor dan Indramayu dapat dilihat pada tabel 5. 
Tabel 5

Karakteristik Rumahtangga Tahan Pangan dan Tidak Tahan Pangan

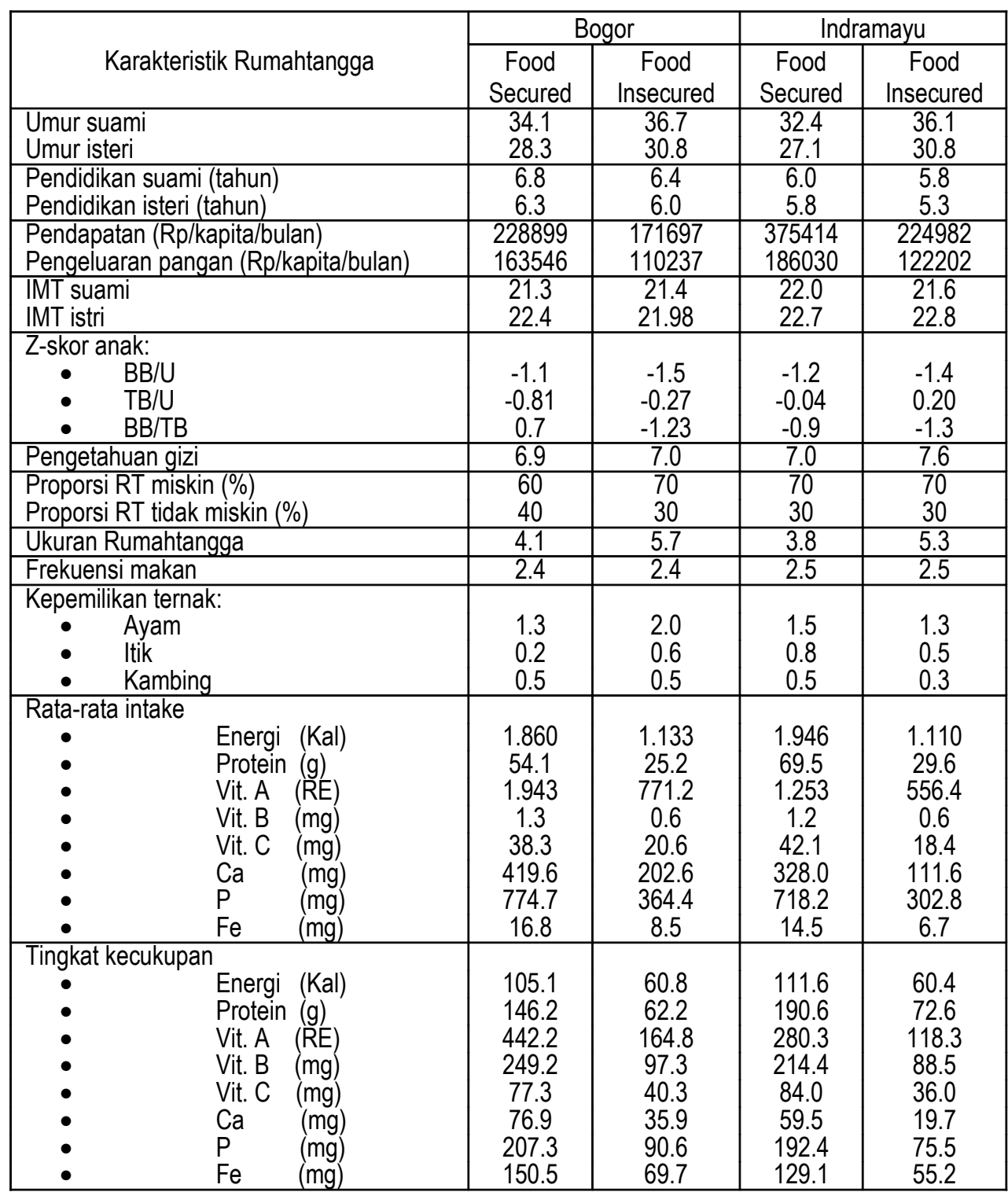

\section{Asupan Pangan}

\section{Konsumsi Energi dan Protein}

Konsumsi energi dan protein dapat mencerminkan ketahanan pangan rumahtangga. Energi dapat diperoleh dari konsumsi karbohidrat, lemak, dan protein.
Karbohidrat bagi masyarakat Indonesia menjadi sumber energi yang utama karena dikonsumsi dalam jumlah banyak sebagai makanan pokok. Jenis-jenis pangan sumber karbohidrat antara lain: beras, jagung, dan singkong. Sementara itu, lemak yang kandungan energinya lebih tinggi daripada 
karbohidrat dikonsumsi dalam bentuk minyak goreng dan lemak asal pangan hewani (baik terlihat maupun tidak terlihat). Jika konsumsi karbohidrat dan lemak kurang, maka sebagian protein akan digunakan sebagai sumber energi. Pangan sumber protein misalnya telur, tempe, atau kacangkacangan.

Tabel 6 menunjukkan bahwa konsumsi energi rumahtangga miskin maupun rumahtangga tidak miskin belum memenuhi angka kecukupannya. Untuk kategori kelompok miskin, rumahtangga di Indramayu mempunyai tingkat kecukupan energi lebih tinggi $(85 \%)$ dibandingkan rumahtangga di Bogor. Untuk kategori kelompok tidak miskin tingkat kecukupan energinya adalah 96\% (Indramayu) dan 92\% (Bogor). Dari Tabel 6 tampak bahwa rumahtangga tidak miskin memiliki tingkat kecukupan energi yang lebih baik dibanding rumahtangga miskin, dan rumahtangga di Indramayu tingkat kecukupan energinya relatif lebih tinggi daripada rumahtangga di Bogor.

Perbedaan mencolok terjadi pada konsumsi protein antara rumahtangga miskin di Bogor dan Indramayu. Tingkat kecukupan protein di Indramayu sudah lebih dari 100\% $(112 \%)$, sedangkan di Bogor baru mencapai $85 \%$. Rumahtangga yang tinggal di pantai (Indramayu) lebih mudah mendapatkan pangan sumber protein (ikan) dengan harga relatif murah, dibandingkan rumahtangga miskin di dataran tinggi yang lebih sulit mendapatkan pangan sumber protein dengan harga terjangkau. Dari Tabel 6 diketahui bahwa tingkat kecukupan protein untuk kelompok rumahtangga tidak miskin baik di Bogor maupun di Indramayu sudah melebihi $100 \%$. Hal ini menunjukkan bahwa rumahtangga tidak miskin tidak mengalami kesulitan untuk memenuhi konsumsi proteinnya.

Tingkat kecukupan protein secara total di daerah pantai (Indramayu) lebih tinggi $(117 \%)$ daripada di daerah pegunungan (Bogor) (91\%). Hal ini dapat dipahami karena rumahtangga di Indramayu lebih mudah mendapatkan ikan (sumber protein) dibandingkan rumahtangga di Bogor. Pangan sumber protein umumnya berharga mahal, namun bagi orang miskin konsumsi tahu, tempe, kacang-kacangan atau ikan asin dapat menjadi kontributor utama terhadap angka kecukupan protein. Kemungkinan lain adalah bahwa nasi selain digunakan sebagai sumber karbohidrat (energi), ternyata juga relatif tinggi kandungan proteinnya. Rumahtangga yang makanan pokoknya nasi juga akan mendapat sumbangan protein yang cukup bermakna.

Kenyataan bahwa tingkat kecukupan protein umumnya lebih tinggi daripada tingkat kecukupan energi (baik untuk kelompok miskin ataupun kategori wilayah pantai/dataran tinggi) menunjukkan pada umumnya masyarakat lebih mudah memenuhi angka kecukupan protein dibandingkan angka kecukupan energi. 
Tabel 6

Rata-rata Konsumsi, Angka Kecukupan, dan Tingkat Kecukupan Energi dan Protein pada Tingkat Rumahtangga

\begin{tabular}{|c|c|c|}
\hline \multirow{2}{*}{ Zat Gizi } & Bogor & Indramayu \\
\hline & Rata-rata & Rata-rata \\
\hline \multicolumn{3}{|l|}{ 1. Energi } \\
\hline \multicolumn{3}{|l|}{ Miskin } \\
\hline - Konsumsi & 1431 & 1514 \\
\hline - Angka Kecukupan (Kal) & 1853 & 1844 \\
\hline - Tingkat Kecukupan (\%) & 80 & 85 \\
\hline \multicolumn{3}{|l|}{ Tidak Miskin } \\
\hline - Konsumsi & 1690 & 1676 \\
\hline - Angka Kecukupan (Kal) & 1882 & 1833 \\
\hline - Tingkat Kecukupan (\%) & 92 & 96 \\
\hline \multicolumn{3}{|l|}{ Miskin + Tidak Miskin } \\
\hline - Konsumsi $\quad$ (Kal) & 1531 & 1562 \\
\hline - Angka Kecukupan (Kal) & 1863 & 1841 \\
\hline - Tingkat Kecukupan (\%) & 85 & 88 \\
\hline \multicolumn{3}{|l|}{ 2. Protein } \\
\hline \multicolumn{3}{|l|}{ Miskin } \\
\hline - Konsumsi & 33 & 43 \\
\hline - Angka Kecukupan (g) & 40 & 40 \\
\hline - Tingkat Kecukupan (\%) & 85 & 112 \\
\hline \multicolumn{3}{|l|}{ Tidak Miskin } \\
\hline - Konsumsi & 40 & 48 \\
\hline - Angka Kecukupan (g) & 41 & 40 \\
\hline - Tingkat Kecukupan (\%) & 103 & 128 \\
\hline \multicolumn{3}{|l|}{ Miskin + Tidak Miskin } \\
\hline - Konsumsi $\quad(\mathrm{g})$ & 35 & 44 \\
\hline - Angka Kecukupan (g) & 40 & 40 \\
\hline - Tingkat Kecukupan (\%) & 91 & 117 \\
\hline
\end{tabular}

\section{Konsumsi Vitamin}

Vitamin adalah zat gizi yang diperlukan dalam jumlah sedikit tapi penting. Di negara sedang berkembang, defisiensi vitamin yang sering terjadi adalah kekurangan vitamin $\mathrm{A}$ yang menyebabkan kebutaan dan melemahnya kekebalan tubuh. Namun, Indonesia sejak tahun 1994 oleh WHO sudah dinyatakan bebas dari masalah kekurangan vitamin $\mathrm{A}$.

Tabel 7 menunjukkan bahwa konsumsi vitamin $A$ di pegunungan (Bogor) umumnya lebih tinggi daripada di pantai (Indramayu) baik untuk rumahtangga miskin maupun tidak miskin. Sementara itu kalau memperhatikan konsumsinya berdasar strata ekonomi terlihat bahwa rumahtangga tidak miskin mengkonsumsi vitamin A lebih tinggi daripada rumahtangga miskin.

Untuk rumahtangga miskin, tingkat kecukupan vitamin A di Bogor adalah 249\%, sedangkan di Indramayu 167\%. Sedangkan untuk rumahtangga tidak miskin, tingkat kecukupan vitamin A di Bogor $248 \%$ dan di Indramayu 207\%. Alasan mengapa rumahtangga di Bogor lebih tinggi konsumsi 
vitamin A-nya dibandingkan dengan rumahtangga di Indramayu adalah karena etnis Sunda (Bogor) lebih menyukai sayuran dibandingkan etnis Jawa
(Indramayu). Hal ini juga ditunjukkan oleh tingginya konsumsi sayuran di Bogor daripada di Indramayu. Sayuran berwarna hijau tua umumnya kaya akan provitamin $\mathrm{A}$.

Tabel 7

Rata-rata Konsumsi, Angka Kecukupan, dan Tingkat Kecukupan Vitamin pada Tingkat Rumahtangga

\begin{tabular}{|c|c|c|}
\hline \multirow{2}{*}{ Vitamin } & Bogor & Indramayu \\
\hline & Rata-rata & Rata-rata \\
\hline \multicolumn{3}{|l|}{ 1. Vitamin $A$} \\
\hline \multicolumn{3}{|l|}{ Miskin } \\
\hline - Konsumsi $\quad(\mathrm{RE})$ & 1112 & 766 \\
\hline - Angka Kecukupan (RE) & 461 & 461 \\
\hline - Tingkat Kecukupan (RE) & 249 & 167 \\
\hline \multicolumn{3}{|l|}{ Tidak Miskin } \\
\hline - Konsumsi & 1303 & 938 \\
\hline - Angka Kecukupan (RE) & 468 & 458 \\
\hline - Tingkat Kecukupan (RE) & 284 & 207 \\
\hline \multicolumn{3}{|l|}{ Miskin + Tidak Miskin } \\
\hline - Konsumsi $\quad(\mathrm{RE})$ & 1176 & 816 \\
\hline - Angka Kecukupan (RE) & 464 & 460 \\
\hline - Tingkat Kecukupan (RE) & 261 & 179 \\
\hline \multicolumn{3}{|l|}{ 2. Vitamin $\mathrm{C}$} \\
\hline \multicolumn{3}{|l|}{ Miskin } \\
\hline - Konsumsi $\quad(\mathrm{mg})$ & 24 & 26 \\
\hline - Angka Kecukupan (mg) & 51 & 51 \\
\hline - Tingkat Kecukupan (mg) & 48 & 51 \\
\hline \multicolumn{3}{|l|}{ Tidak Miskin } \\
\hline - Konsumsi $\quad(\mathrm{mg})$ & 32 & 30 \\
\hline - Angka Kecukupan (mg) & 51 & 51 \\
\hline - Tingkat Kecukupan (mg) & 63 & 61 \\
\hline \multicolumn{3}{|l|}{ Miskin + Tidak Miskin } \\
\hline - Konsumsi $\quad(\mathrm{mg})$ & 27 & 27 \\
\hline - Angka Kecukupan (mg) & 51 & 51 \\
\hline - Tingkat Kecukupan (mg) & 53 & 54 \\
\hline
\end{tabular}

Vitamin C saat ini dikenal sebagai master of nutrient karena diketahui fungsinya bukan hanya sekedar untuk anti sariawan. Vitamin C adalah pengendali kolesterol dalam tubuh dan juga bermanfaat untuk memperbaiki kekebalan tubuh. Konsumsi vitamin C secara total masih belum memenuhi angka kecukupannya. Di Bogor tingkat kecukupan vitamin $\mathrm{C}$ baru mencapai $53 \%$ dan di Indramayu 54\%. Untuk kelompok miskin tingkat kecukupannya adalah 48\% (Bogor) dan 51\% (Indramayu), sedangkan untuk kelompok tidak miskin adalah 63\% (Bogor) dan 61\% (Indramayu).

Salah satu sumber vitamin C adalah buah. Rendahnya konsumsi vitamin $\mathrm{C}$ 
mungkin disebabkan kurangnya konsumsi buah pada rumahtangga responden baik di Bogor maupun Indramayu. Hal ini tentu ada kaitannya dengan harga buah yang relatif mahal.

\begin{abstract}
Konsumsi Mineral
Kalsium adalah salah satu mineral yang sangat penting bagi kesehatan tubuh. Fungsi utama kalsium terkait dengan pembentukan kerangka tubuh dan gigi.
\end{abstract}

Tabel 8

Rata-rata Konsumsi, Angka Kecukupan, dan Tingkat Kecukupan Mineral dalam Rumahtangga

\begin{tabular}{|c|c|c|}
\hline \multirow{2}{*}{ Vitamin } & Bogor & Indramayu \\
\hline & Rata-rata & Rata-rata \\
\hline \multicolumn{3}{|l|}{ 1. Kalsium (Ca) } \\
\hline \multicolumn{3}{|l|}{ Miskin } \\
\hline - Konsumsi $\quad(\mathrm{mg})$ & 271 & 188 \\
\hline - Angka Kecukupan (mg) & 560 & 564 \\
\hline - Tingkat Kecukupan (mg) & 49 & 34 \\
\hline \multicolumn{3}{|l|}{ Tidak Miskin } \\
\hline - Konsumsi $\quad(\mathrm{mg})$ & 290 & 202 \\
\hline - Angka Kecukupan (mg) & 570 & 563 \\
\hline - Tingkat Kecukupan (mg) & 52 & 36 \\
\hline \multicolumn{3}{|l|}{ Miskin + Tidak Miskin } \\
\hline - Konsumsi $\quad(\mathrm{mg})$ & 277 & 192 \\
\hline - Angka Kecukupan (mg) & 563 & 564 \\
\hline - Tingkat Kecukupan (mg) & 50 & 35 \\
\hline \multicolumn{3}{|l|}{ 2. Zat Besi (Fe) } \\
\hline \multicolumn{3}{|l|}{ Miskin } \\
\hline - Konsumsi $\quad(\mathrm{mg})$ & 11 & 9 \\
\hline - Angka Kecukupan (mg) & 12 & 12 \\
\hline - Tingkat Kecukupan (mg) & 94 & 79 \\
\hline \multicolumn{3}{|l|}{ Tidak Miskin } \\
\hline - Konsumsi $\quad(\mathrm{mg})$ & 12 & 10 \\
\hline - Angka Kecukupan (mg) & 12 & 12 \\
\hline - Tingkat Kecukupan (mg) & 105 & 92 \\
\hline \multicolumn{3}{|l|}{ Miskin + Tidak Miskin } \\
\hline $\begin{array}{ll}- \text { Konsumsi } & (\mathrm{mg}) \\
\end{array}$ & 11 & 10 \\
\hline - Angka Kecukupan (mg) & 12 & 12 \\
\hline - Tingkat Kecukupan (mg) & 98 & 83 \\
\hline
\end{tabular}

Tabel 8 menunjukkan bahwa konsumsi kalsium secara keseluruhan masih relatif rendah. Rata-rata tingkat kecukupan kalsium di Bogor adalah 50\% dan di Indramayu 35\%. Untuk kelompok tidak miskin, tingkat kecukupannya sedikit lebih tinggi daripada kelompok miskin yaitu masing-masing 52\% dan 49\% di Bogor serta $36 \%$ dan $34 \%$ di Indramayu.

Sumber kalsium yang utama adalah susu. Namun di Indonesia susu masih dianggap minuman mahal, biasanya susu hanya diminum oleh anak-anak sampai usia sekitar 5 (lima) tahun. Sesudah mencapai 
usia 5 (lima) tahun susu seringkali tidak diberikan lagi oleh orangtuanya. Di lokasi penelitian, kemungkinan besar konsumsi susu juga rendah sehingga asupan kalsium belum mencapai tingkat kecukupan $100 \%$. Zat besi (Fe) berperan untuk mencegah anemia. Masalah kekurangan zat besi masih menjadi problem di Indonesia terutama di kalangan ibu hamil dan anak-anak. Sumber zat besi yang utama adalah pangan hewani seperti daging dan telur. Selain itu zat besi juga dapat diperoleh dari pangan nabati khususnya sayuran berdaun hijau tua.

Tabel 8 menunjukkan bahwa tingkat kecukupan zat besi di Bogor lebih tinggi (98\%) dibandingkan di Indramayu (83\%). Pada kelompok miskin, tingkat kecukupannya adalah $94 \%$ (Bogor) dan $79 \%$ (Indramayu); sedangkan pada kelompok tidak miskin adalah 105\% (Bogor) dan 92\% (Indramayu). Diperkirakan sumber zat besi pada rumahtangga di lokasi penelitian adalah pangan nabati karena pangan hewani (daging) harganya mahal sehingga jarang dikonsumsi.

\section{KESIMPULAN}

Faktor-faktor yang berpengaruh nyata terhadap ketahanan pangan rumahtangga adalah jumlah anggota rumahtangga, umur suami, dan kategori keluarga.

a. Jumlah anggota keluarga berpengaruh nyata terhadap tingkat kecukupan energi. Semakin tinggi jumlah anggota keluarga maka semakin rendah tingkat kecukupan energi. Namun demikian jumlah anggota keluarga hanya dapat menjelaskan keragaman tingkat kecukupan protein sebesar $9.43 \%$.

b. Jumlah anggota keluarga, umur suami dan kategori rumahtangga berpengaruh nyata terhadap tingkat kecukupan protein. Semakin kecil jumlah anggota keluarga, semakin tua suami maka semakin tinggi tingkat kecukupan protein. Keluarga miskin memiliki tingkat kecukupan protein lebih rendah daripada keluarga tidak miskin. Namun demikian jumlah anggota keluarga, umur suami dan kategori keluarga tersebut hanya dapat menjelaskan keragaman tingkat kecukupan protein sebesar $9.57 \%$.

c. Jumlah anggota keluarga dan umur suami berpengaruh nyata terhadap ketahanan pangan. Semakin kecil jumlah anggota keluarga dan semakin tua suami, maka semakin tinggi peluang rumahtangga menjadi tahan pangan.

Peneliti mengucapkan terima kasih dan apresiasi kepada Neys von Hoogstraten Foundation (NHF) Belanda selaku penyandang dana penelitian atas kesempatan yang telah diberikan sehingga penelitian ini dapat dilaksanakan.

\section{RUJUKAN}

1. Hardinsyah \& D. Martianto. 2001. Pembangunan Ketahanan pangan Berbasis Agribisnis dan Pemberdayaan Masyarakat. Prosiding Seminar Nasional Pemberdayaan Masyarakat untuk Mencapai Ketahanan Pangan dan pemulihan ekonomi. PSKPG IPB. Bogor.

2. Atmojo, S.M., H. Syarief, D. Sukandar, \& M. Latifah. 1995. Laporan studi Identifikasi Daerah Rawan Pangan. Proyek Pengembangan Diversifikasi Pangan dan Gizi. Departemen Pertanian- Jurusan GMSK Fakultas Pertanian IPB. Bogor.

3. Chung, K., L. Haddad, J. Ramakrishna \& F. Riely. 1997. Identifying the Food Insecure, the Application on Mixed Method Appproaches in India. International Food Policy Research Institute. Washington D.C. 
4. Maxwell, S. \& T. R. Frankenberger. 1992. Household Food Security: Concepts, Indicators, Measurements, A Technical Review. Rome: International Fund for Agricultural Development/ United Nations Children's Fund.

5. Harper, L.J., B.J. Deaton, \& J.A. Driskel. 1985. Pangan, Gizi dan Pertanian. UI Press. Jakarta. 